\title{
Development of Biomimetic Sensor for Fast and Sensitive Detection of Norfloxacin
}

\author{
Daniel Ferreira Gobatto ${ }^{1}$, Ademar Wong ${ }^{1}$, Marcos Roberto de Vasconcelos Lanza ${ }^{2}$ and \\ Maria Del Pilar Taboada Sotomayor ${ }^{*}, 1$
}

${ }^{1}$ Departamento de Química Analítica - IQ, Universidade Estadual Paulista, 14801-970 Araraquara-SP, Brazil
${ }^{2}$ Departamento de Química e Física Molecular-IQSC, Universidade de São Paulo, 13560-970 São Carlos-SP, Brazil

\begin{abstract}
A biomimetic sensor is proposed as a promising new analytical method for determination of norfloxacin (NF) in pharmaceuticals. The sensor was prepared by modifying a glassy carbon electrode surface with a Nafion ${ }^{\circledR}$ membrane doped with poly(copper phthalocyanine) complex [poly-CuPc]. Amperometric measurements carried out with the sensor under an applied potential of $-0.05 \mathrm{~V} v s \mathrm{Ag} \mid \mathrm{AgCl}$ in $0.1 \mathrm{~mol} \mathrm{~L}^{-1}$ acetic acid containing $1.5 \times 10^{-3} \mathrm{~mol} \mathrm{~L}^{-1}$ hydrogen peroxide showed a linear response range from $2.0 \times 10^{-4}$ to $1.2 \times 10^{-3} \mathrm{~mol} \mathrm{~L}^{-1}$. Selectivity and interference studies were also performed. A sensor response mechanism is proposed, based on the experimental evidence. Recovery studies were carried out using environmental samples, in order to evaluate the sensor's potential for use with these sample classes. Finally, sensor performance was evaluated using analyses of commercial formulations.
\end{abstract}

Keywords: Norfloxacin, fluoroquinolones, biomimetic sensors, poly(copper phthalocyanine).

\section{INTRODUCTION}

Analytical chemistry includes the development of methods, processes and techniques applied to natural samples, in order to characterize or quantify chemical species. Electroanalytical methods comprise a number of quantitative analytical techniques, which are based on the electrical properties of the analyte in solution [1]. The increasing use of electroanalytical methodologies, for monitoring drugs in biological fluids $[2,3]$ and pharmaceutical formulations $[4,5]$, as well as pesticides and vitamins in foods and other matrices [6,7], is directly related to their simplicity, sensitivity, selectivity and cost, when compared with other analytical methods such as high performance liquid chromatography (HPLC).

In recent years, use of biomimetic chemistry has expanded in many branches of science, and in electroanalytical chemistry innovations include the development of biomimetic catalysts employed in construction of biomimetic sensors [8].

Biomimetic sensors (or enzymeless biosensors) are based on the use of synthetic analogues of natural enzymes $[9,10]$, and result from attempts to produce chemical sensors that are more stable and durable than conventional biosensors based on biological materials such as enzymes or antibodies. These devices aim to overcome limitations of conventional enzymatic biosensors, such as availability, cost and enzyme instability, as well as to improve electronic transfer between electrode/active site (biomimetic catalyst/substrate), since in

*Address correspondence to this author at the Departamento de Química Analítica - IQ, Universidade Estadual Paulista,14801-970 Araraquara-SP, Brazil; Tel: +55-16330-16620; E-mail: mpilar@iq.unesp.br biomimetic sensors the "active site" is free, in contrast to enzymes, where the active site is surrounded by a dense layer of residual amino acids $[9,10]$.

The development of biomimetic sensors is a relatively new field of research, and has only recently been reported in the literature [11-14]. Published work has demonstrated that synthesized simple inorganic compounds, and/or complexes of transition metals, are capable of catalyzing substrates in a similar fashion as the corresponding enzymes, thus allowing the construction of biomimetic sensors possessing high selectivity and sensitivity.

The origin of fluoroquinolones is intrinsically related to that of quinolones. Nalidixic acid (Chart 1b), the first quinolone to present antibacterial activity, was synthesized and patented by Lescher and collaborators in 1962. The first compound with a fluorine atom at position C-6 was flumequine, patented in 1973, which presented important evidence that this class of drugs could be used to fight bacterial infections. However, the great advance in chemotherapy using antibacterial fluoroquinolones occurred in the late $1970 \mathrm{~s}$, when the introduction of a fluorine atom at position C-6, and a piperazyl group in position C-7 of the nalidixic acid molecule, produced the norfloxacin (NF) drug (Chart 1a), patented in 1978, which showed a broad spectrum of antimicrobial activity [15].

Many analytical methods for the quantification of fluoroquinolones have been described in the literature, based on simple methodologies including spectrophotometry [16], chemiluminescence [17] and fluorescence [18,19], or other more complex and time-consuming techniques based on high performance liquid chromatography with UV [20], fluorescence $[20,21]$, tandem mass spectrometry [22-24] or 
<smiles>CCn1cc(C(=O)O)c(=O)c2cc(F)c(N3CCNCC3)cc21</smiles>

(c)<smiles>O=C(O)c1cn(C2CC2)c2cc(N3CCNCC3)c(F)cc2c1=O</smiles>

(e)<smiles>CC(=O)Oc1ccccc1C(=O)O</smiles>

(g)<smiles>C[C@H](C[Hg])C(=O)N1CCC[C@H]1C(=O)O</smiles>

(i)<smiles>O=C(O)Cc1ccccc1Nc1c(Cl)cccc1Cl</smiles>

(b)<smiles>CCn1cc(C(=O)O)c(=O)c2ccc(C)nc21</smiles>

(d)<smiles>CC(=O)Nc1ccc(O)cc1</smiles><smiles>CC1(C)SC2[C@@H](NC(=O)[C@@H](N)c3ccc(O)cc3)C(=O)N2[C@H]1C(=O)O</smiles>

(h)<smiles>[CH][C@H](NC(=O)C(Cl)Cl)[C@H](O)c1ccc([N+](=O)[O-])cc1</smiles>

(j)<smiles>Cc1c(N(C)CS(=O)(=O)O)c(=O)n(-c2ccccc2)n1C</smiles>

Chart 1. Chemical structures: (a) norfloxacin; (b) nalidixic acid; (c) ciprofloxacin; (d) acetaminophen; (e) acetylsalicylic acid; (f) amoxicillin; (g) captopril; (h) chloramphenicol; (i) diclofenac and (j) dipyrone.

pneumatically assisted electrospray ionization mass spectrometry [25] detection. Other sophisticated analytical techniques reported to identify and quantify fluoroquinones have included surface desorption atmospheric pressure chemical ionization tandem mass spectrometry, micellar liquid chromatography [26] and capillary electrophoresis [27]. Solid phase extraction has been used for sample cleanup and pre-concentration, considering the low concentrations expected in environmental, food and biological samples $[21,23,24]$.

Electrochemical detection of norfloxacin using direct current and differential pulse polarographic reduction has been studied in a mixed electrolyte containing the organic solvent dimethyl formamide. The reduction wave in the range -0.95 to $-1.05 \mathrm{~V}$ was observed in strongly acidic medium $(\mathrm{pH}<1)$ [28].

Antibiotics, an important pharmaceutical group that includes norfloxacin and analogue compounds, are considered a new class of "pseudopersistent" contaminant, due to their continual input into the environment and permanent presence [22], as a consequence of their potent antimicrobial activity. An increasing number of studies worldwide have demonstrated the presence of various veterinary antibiotics, including fluoroquinolone derivates, in animal wastes, surface and ground waters, river sediments and soils, at concentrations that could have potential ecosystem impacts [29-32]. 
Efforts to quantify pharmaceuticals in environmental samples have intensified in recent years, following recognition of the occurrence, fate and potentially toxic effects of many of these compounds [22]. However, it is important that new analytical methods used to identify and quantify these compounds should be environmentally friendly.

This paper presents the development of a biomimetic sensor, for rapid and selective determination of norfloxacin, as an alternative analytical tool to existing analytical methods. For this purpose, poly(copper phthalocyanine) (Chart 2), was evaluated as a biomimetic catalyst in the catalysis of NF.

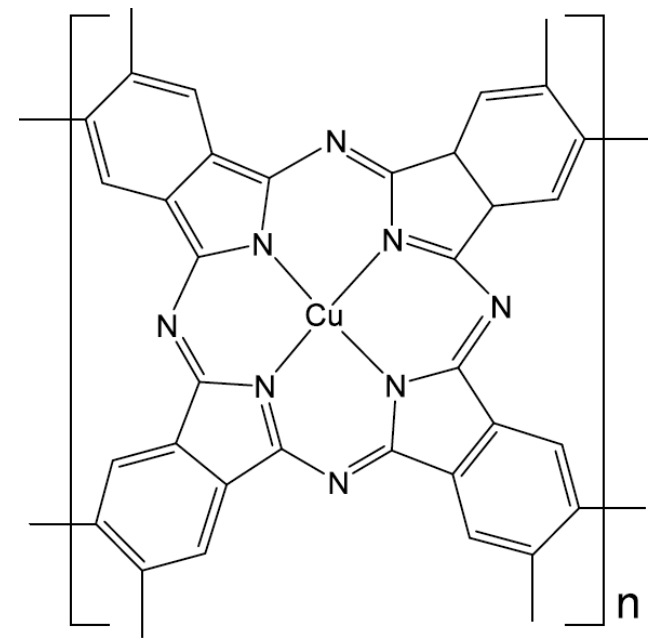

Chart 2. Chemical structure of the poly-CuPc complex.

\section{EXPERIMENTAL}

\subsection{Chemicals and Solutions}

All chemicals used were analytical or HPLC grade. Poly(copper phthalocyanine) [poly-CuPc], 5\% (m/v) Nafion $^{\circledR}$ solution, norfloxacin, ciprofloxacin, nalidixic acid, paracetamol, acetylsalicylic acid, captopril, chloramphenicol, dipyrone, amoxicillin, diclofenac, mineral oil and graphite powder were acquired from Sigma-Aldrich. Acetic acid and $N, N$-dimethylformamide (DMF) were acquired from Synth (São Paulo, Brazil). All HPLC grade solvents were from Tedia (Rio de Janeiro, Brazil).

\subsection{Biomimetic Sensor Construction}

First, a solution containing $5 \mathrm{mg} \mathrm{mL}^{-1}$ of poly-CuPc in DMF was prepared. Then, the surface of a glassy carbon (GC) electrode (Metrohm ${ }^{\circledR}$, Switzerland), with a geometrical area of $0.126 \mathrm{~cm}^{2}$, was cleaned according to the procedure described in the literature [33]. After cleaning the electrode, $150 \mu \mathrm{L}$ of poly-CuPc solution was mixed with $100 \mu \mathrm{L}$ of $5 \%$ $(\mathrm{m} / \mathrm{v})$ Nafion $^{\circledR}$ solution, and an aliquot of $125 \mu \mathrm{L}$ of this mixture placed on the surface of the electrode. Finally, the solvent was evaporated at room temperature during $6 \mathrm{~h}$, forming a thin green film.

\subsection{Electrochemical Measurements and Flow Manifold}

The electrochemical experiments were conducted at room temperature in a conventional three-electrode cell, with the modified glassy carbon electrode (GCE) used as the working electrode and an $\mathrm{Ag} \mid \mathrm{AgCl}\left(\mathrm{KCl}_{\text {sat }}\right)$ electrode and a platinum wire as the reference and counter electrodes, respectively. Data acquisition was performed with a PalmSense potentiostat (Palm Instruments BV, The Netherlands) interfaced with a microcomputer for potential control and data acquisition. The amperometric measurements were carried out using previously optimized $0.1 \mathrm{~mol}$ $\mathrm{L}^{-1}$ acetic acid and a potential of $-50 \mathrm{~V}$ vs $\mathrm{Ag} \mid \mathrm{AgCl}\left(\mathrm{KCl}_{\text {sat }}\right)$ with continuous recording of the current until a steady state was reached (after approximately $60 \mathrm{~s}$ ). At this point, recording was interrupted in order to add aliquots $(\mu \mathrm{L})$ of $\mathrm{H}_{2} \mathrm{O}_{2}$ or norfloxacin (NF) standard (or sample) solution to the electrolyte, with stirring of the solution for 10 seconds to ensure complete homogenization. The current was then again monitored in the quiescent solution for $10 \mathrm{~s}$, during which time a new steady state was achieved. The analytical curve was obtained by successive additions of NF standard solutions.

\subsection{HPLC Analysis}

The results obtained using the proposed sensor were validated by comparison with a chromatographic method based on HPLC [34]. Chromatographic analyses were performed using a Shimadzu ${ }^{\circledR}$ Model 20A liquid chromatograph coupled to an UV/Vis detector (SPD-20A), equipped with an autosampler (SIL-20A) and a degasser (DGU-20A5), and controlled by a personal computer. $\mathrm{A}_{18}$ column $(250 \times 4.6 \mathrm{~mm}$, Shim-Pack CLC-ODS $)$ was used, housed in an oven $\left(\right.$ Shimadzu ${ }^{\circledR}$ CTO $\left.-10 \mathrm{AS}\right)$ maintained at $30{ }^{\circ} \mathrm{C}$. The mobile phase was a mixture of acetonitrile and a solution of $\mathrm{H}_{3} \mathrm{PO}_{4}: \mathrm{HNa}_{2} \mathrm{PO}_{4}$ adjusted to $\mathrm{pH} 3.0$, in a ratio of

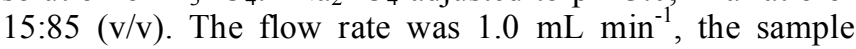
injection volume $20 \mu \mathrm{L}$, and the detector absorption wavelength $279 \mathrm{~nm}$.

\subsection{Pharmaceutical Formulation Analysis}

Quantification of norfloxacin in five commercial formulations was carried out according to the multiple standard additions method, using the proposed sensor. To prepare each sample solution, ten tablets were ground and homogenized in a mortar, then a suitable amount of triturated sample was weighed out and dissolved in 3 parts of deionized water and 7 parts of $0.1 \mathrm{~mol} \mathrm{~L}^{-1} \mathrm{H}_{2} \mathrm{SO}_{4}$ solution (as for NF standard solutions), followed by a filtration step in order to remove any insoluble substances present in the tablets.

\subsection{Aquatic Sample Analysis}

Five water samples collected from rivers near the city of Araraquara (298 km from São Paulo, Brazil) were enriched with $1.25 \times 10^{-2} \mathrm{~mol} \mathrm{~L}^{-1}$ of $\mathrm{NF}$, and then diluted to within the linear range of the sensor, in order to calculate recoveries.

\section{RESULTS AND DISCUSSION}

\subsection{Electrochemical Characterization of the Sensor Response}

The voltammetric behavior of NF on a glassy carbon electrode, modified with Nafion ${ }^{\circledR}$ film (either undoped or doped with poly-CuPc complex), is illustrated in Fig. (1). It can be seen that for the GCE with undoped Nafion ${ }^{\circledR}$ film, no difference was observed after NF addition (Fig. 1, curve b). 
Using the Nafion ${ }^{\circledR}$ film sensor doped with the complex (Fig. 1, curve d), an increase of the cathodic current was observed from $0.2 \mathrm{~V} v s \mathrm{Ag} \mid \mathrm{AgCl}$ after NF addition, as the potential became more negative. In order to evaluate the behavior of the system at more negative potentials, cyclic voltammograms were obtained in a potential window between -0.5 and $0.3 \mathrm{~V}$ vs $\mathrm{Ag} \mid \mathrm{AgCl}$ (Fig. 2A). The presence of a redox couple, corresponding to $\mathrm{Cu}^{2+} / \mathrm{Cu}^{+}$in the electrolyte solution, can be clearly observed (dotted line) at 0.05 (peak I) and at -0.16 (peak III). Another anodic peak (II, at $0.07 \mathrm{~V})$ can be attributed to oxidation of the phthalocyanine groups, analogous to the behavior of the porphyrin ring in compound I of the peroxidase oxidized enzyme [35], or that of $\mathrm{Cu}^{3+}$ in the poly(copper phthalocyanine) complex. After addition of NF, a decrease in the oxidation current intensity was clearly observed for peaks I and II, with an increase of the reduction current, which can be used for NF quantification.

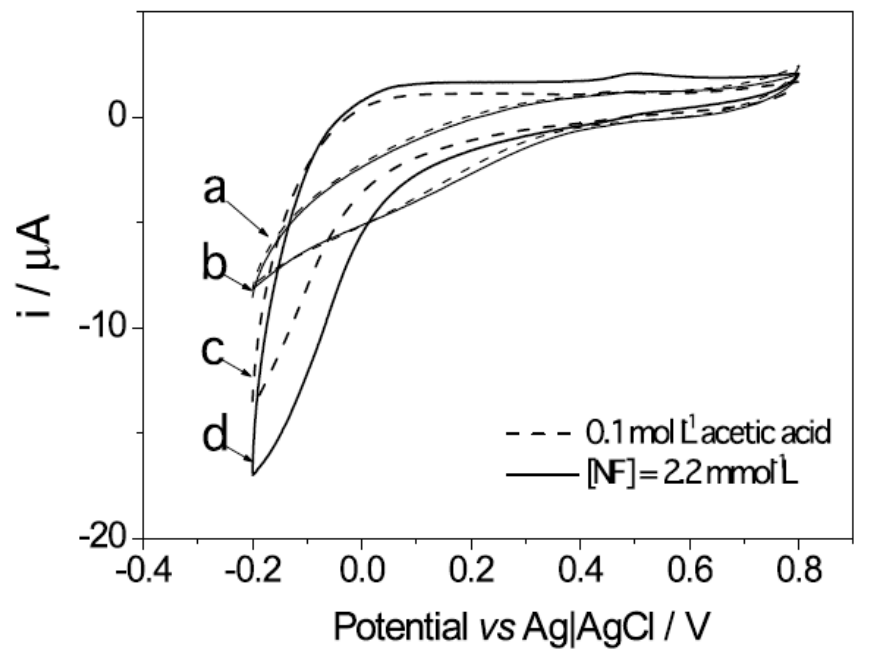

Fig. (1). Voltammetric profiles for undoped (a and b) and doped Nafion ${ }^{\circledR}$ films with poly-CuPc (c and d) in $0.1 \mathrm{~mol} \mathrm{~L}^{-1}$ acetic acid solution, in the presence (solid line) and absence (dashed line) of NF. Potential scan rate $(v)=20 \mathrm{mV} \mathrm{s}^{-1}$.

It is well known that for some copper enzymes [36-39] or their biomimetic catalysts [11] the catalytic mechanisms involve the generation of a copper-hydroperoxy species $\left(\mathrm{Cu}^{2+}-\mathrm{O}-\mathrm{O}-\mathrm{H}\right)$, in order to obtain a hydroxylated product, and that $\mathrm{Cu}^{2+}-\mathrm{O}-\mathrm{O}-\mathrm{H}$ can be obtained in the presence of $\mathrm{H}_{2} \mathrm{O}_{2}$ and $\mathrm{Cu}^{2+}$ ions [11]. The influence of hydrogen peroxide on the sensor response can be seen from the cyclic voltammograms (Fig. 2B), and can be explained based on the copper enzyme catalytic cycle (Fig. 3). In the enzyme, the initial chemical event is proposed to be transfer of two electrons and one proton, from the copper sites $\left(\mathrm{Cu}^{+}\right)$and an active site on the acidic group of the protein, respectively, to oxygen, to yield a copper-hydroperoxy intermediate (Fig. 3). Cleavage of the $\mathrm{O}-\mathrm{O}$ bond and hydrogen extraction from the substrate forms water, copper-oxo and the substrate radical, which subsequently combine to form the hydroxylated product.

In order to confirm the influence of $\mathrm{O}_{2}$ and $\mathrm{H}_{2} \mathrm{O}_{2}$ on sensor response, four amperograms (Fig. 4) were recorded at an applied potential of $50 \mathrm{mV} v s \mathrm{Ag} \mid \mathrm{AgCl}$. It can be clearly observed that in the absence of $\mathrm{O}_{2}$ and $\mathrm{H}_{2} \mathrm{O}_{2}$ (Fig. 4, curve A), practically no current reduction occurred. If $\mathrm{H}_{2} \mathrm{O}_{2}$ was added prior to NF additions, in the absence of $\mathrm{O}_{2}$ higher reduction currents were observed (Fig. 4, curve B). Since a current reduction increase was observed in the cyclic voltammograms without $\mathrm{H}_{2} \mathrm{O}_{2}$ addition (Fig. 2), the amperograms were recorded under this condition (Fig. 4, curve $\mathbf{C}$ ). There was an increase in the current reduction after $\mathrm{NF}$ addition, as expected. Finally, in the presence of $\mathrm{O}_{2}$ (airequilibrated solution), with $\mathrm{H}_{2} \mathrm{O}_{2}$ added prior to $\mathrm{NF}$ additions, the highest current reductions were obtained (Fig. 4, curve D). These results can be explained by considering that both the $\mathrm{Cu}^{+}$and the $\mathrm{Cu}^{2+}$ ions participate in the copperhydroperoxy species formation, which is possible in the presence of $\mathrm{O}_{2}$ and $\mathrm{H}_{2} \mathrm{O}_{2}$, respectively, for cuprous and cupric ions.
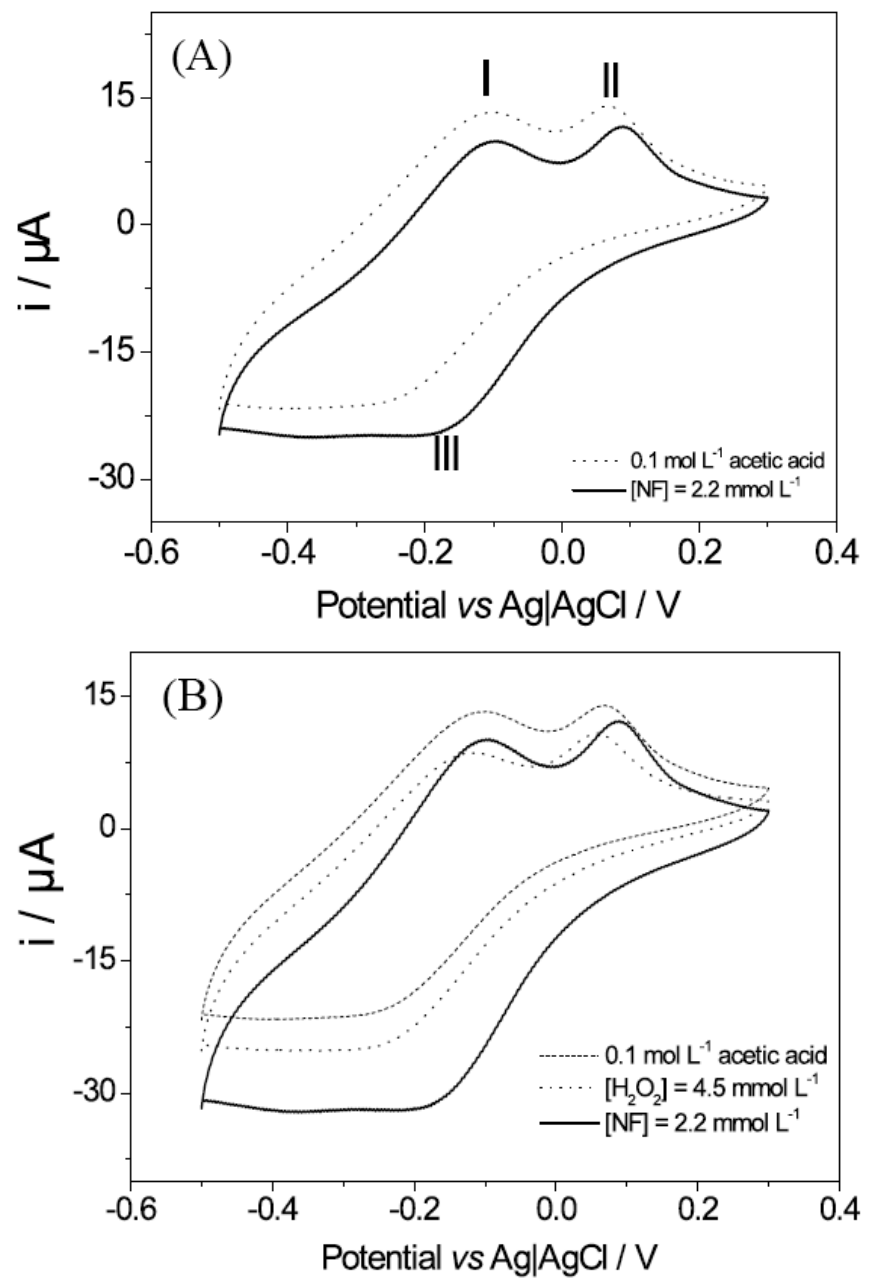

Fig. (2). Voltammetric profiles for the proposed sensor. (A) $0.1 \mathrm{~mol}$ $\mathrm{L}^{-1}$ acetic acid solution in the absence of $\mathrm{H}_{2} \mathrm{O}_{2}$ and presence of NF. (B) $0.1 \mathrm{~mol} \mathrm{~L}^{-1}$ acetic acid solution in the presence of $\mathrm{H}_{2} \mathrm{O}_{2}$ and $\mathrm{NF}$. $\mathrm{V}=20 \mathrm{mV} \mathrm{s}^{-1}$

Cyclic voltammetry was performed at various scan rates $(v)$, in order to investigate whether the electrochemical behavior corresponded to an electrocatalytic process. It is known that a catalytic system behaves as an electrochemical system controlled by diffusion [40]. The results obtained with the sensor are shown in Fig. (5), where a linear dependence $(\mathrm{R}=0.9967)$ can be seen between the cathodic current and the square root of the scan rate, in the potential range between 2 and $200 \mathrm{mV} \mathrm{s}^{-1}$, indicating that the 


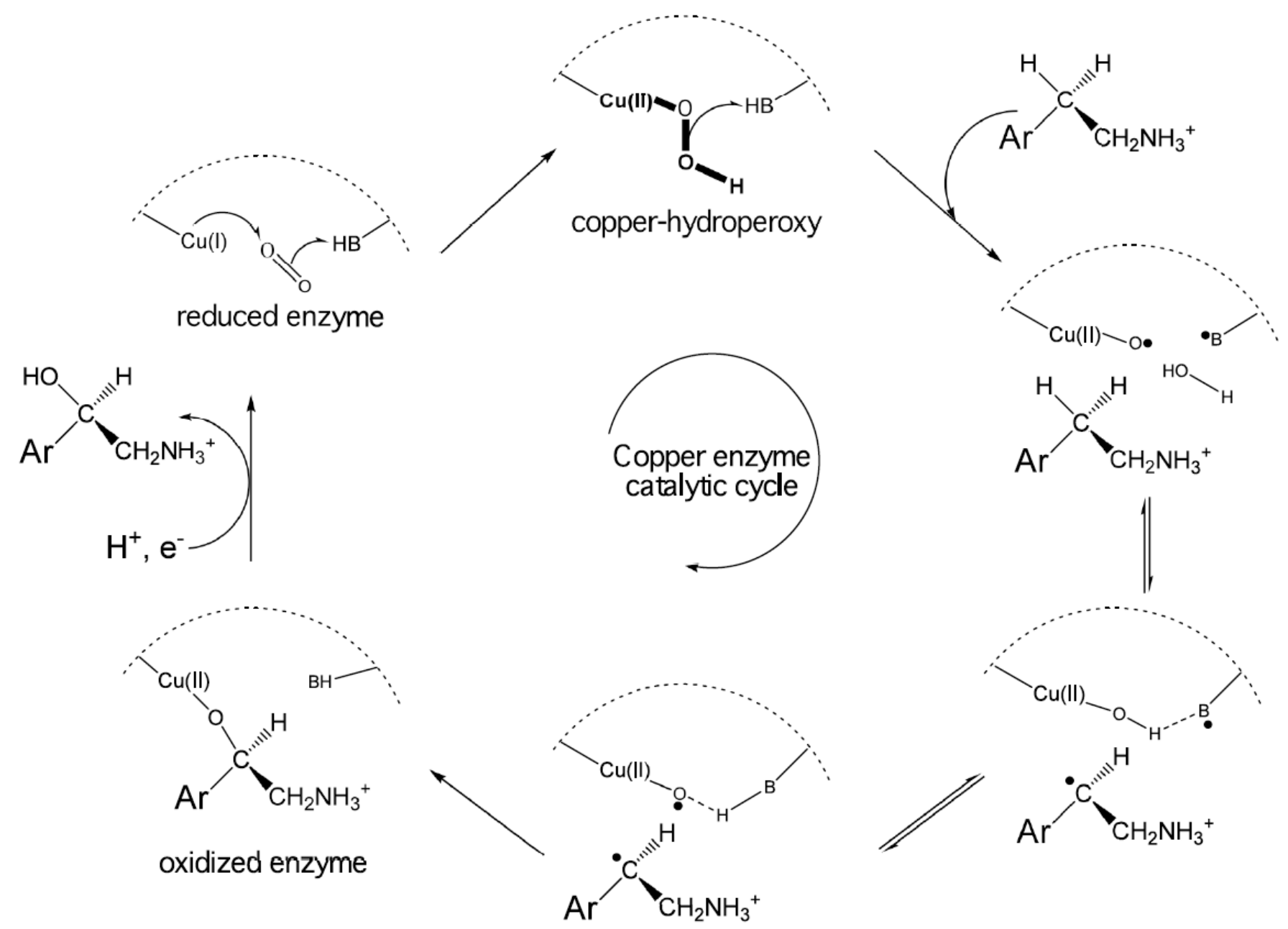

Fig. (3). Mechanism for dopamine- $\beta$-monoxigenase, using as an example the hydrocarbon hydroxylation of the dopamine molecule, in which the copper-hydroperoxy species is formed.

electrochemical system was controlled by a diffusion process.

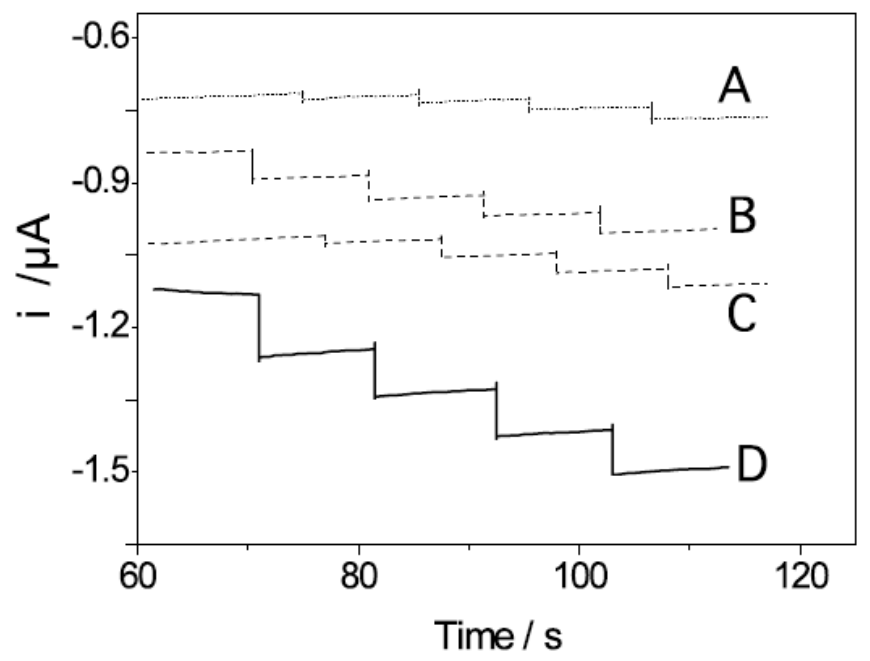

Fig. (4). Profile of response obtained with the proposed sensor in anaerobic (A and $\mathbf{B}$ ) and in aerobic (C and D) conditions, for successive additions of $2.0 \times 10^{-4} \mathrm{~mol} \mathrm{~L}^{-1} \mathrm{NF}$. Curves $\mathbf{A}$ and $\mathbf{C}$ were obtained in the absence of $\mathrm{H}_{2} \mathrm{O}_{2}$, and curves $\mathbf{B}$ and $\mathbf{D}$ in the presence of $1.5 \times 10^{-3} \mathrm{~mol} \mathrm{~L}^{-1} \mathrm{H}_{2} \mathrm{O}_{2}$. Measurements were carried out in $0.1 \mathrm{~mol} \mathrm{~L}^{-1}$ acetic acid, applying a potential of $0.050 \mathrm{~V}$ vs $\mathrm{Ag} \mid \mathrm{AgCl}$.

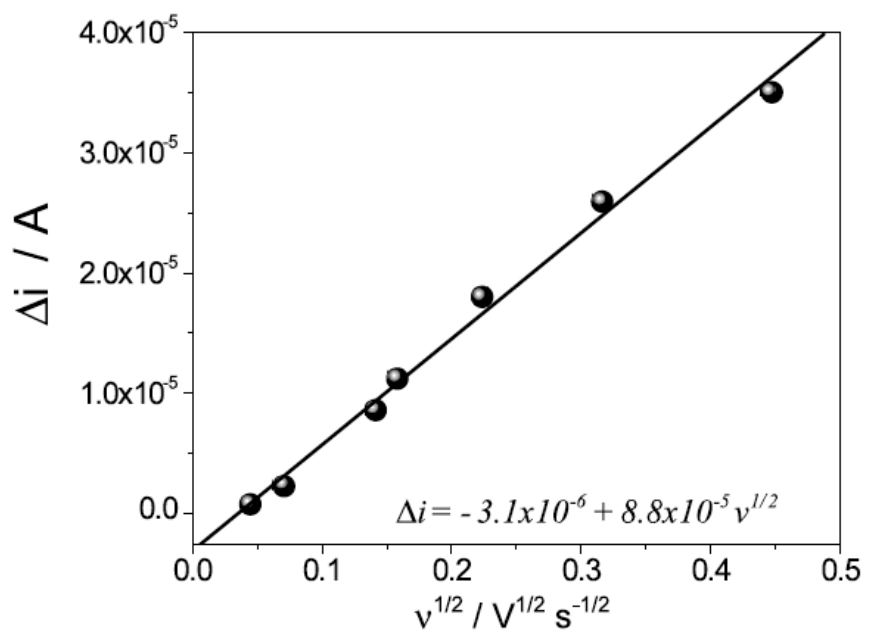

Fig. (5). Linear profile of the variation of the current $(\Delta \mathrm{i})$ as a function of the square root of the scan rate $\left(v^{1 / 2}\right)$.

Additionally, when the scan rate-normalized current $(\Delta \mathrm{i}$ $v^{-1 / 2}$ ) was plotted $v s . \quad v$ (Fig. 6), the plot shape was characteristic of a typical electrocatalytical reduction process $[12,33,41]$, indicating that the sensor response results first 
from a chemical reaction between the analyte and the copper complex (catalyst), with further electrochemical processes involving catalytic site regeneration $\left(\mathrm{Cu}^{2+} / \mathrm{Cu}^{+}\right.$redox process). The current was proportional to the $\mathrm{NF}$ concentration, and associated with the reduction of copper ions, as evidenced by the increase of the reduction current in the cyclic voltammograms shown in Fig. (2).

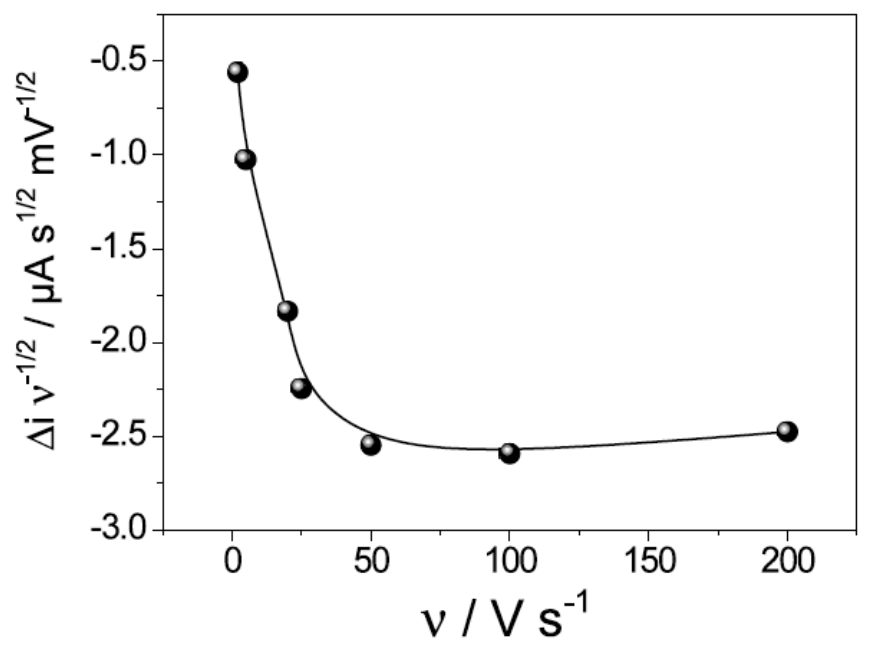

Fig. (6). Plot of the current variation $(\Delta \mathrm{i})$, normalized by the square root of the scan rate $\left(v^{1 / 2}\right)$, as a function of the scan rate $(v)$. Measurements were carried out in $0.1 \mathrm{~mol} \mathrm{~L}^{-1}$ acetic acid containing $4.5 \mathrm{mmol} \mathrm{L}^{-1} \mathrm{H}_{2} \mathrm{O}_{2}$ and $2.2 \mathrm{mmol} \mathrm{L}^{-1} \mathrm{NF}$.

The combined experimental evidence suggests the mechanism shown in Fig. (7). In this mechanism the response obtained in the absence of $\mathrm{H}_{2} \mathrm{O}_{2}$ is shown. Initially, the cupric ion is reduced, at an adequate applied potential, to the cuprous ion observed in the absence of NF (Fig. 2). In the presence of $\mathrm{O}_{2}$ and $\mathrm{H}^{+}$, the formation of copperhydroperoxy occurs, which is recognized as the catalytic species for the sensor response. In the presence of NF, the oxidation of the analyte leads to the reduction of $\mathrm{Cu}^{2+}-\mathrm{O}-\mathrm{O}-$ $\mathrm{H}$ to $\mathrm{Cu}^{2+}$, which is then reduced to the cuprous ion, on the electrode surface at the applied potential, as evidenced in Fig. (6). This suggests an EC process for the sensor response, with the current being proportional to the NF concentration, and associated with the reduction of cupric to cuprous ions. Additionally, the highest currents obtained in the presence of hydrogen peroxide can be explained by formation of $\mathrm{Cu}^{2+}-\mathrm{O}-\mathrm{O}-\mathrm{H}$ from $\mathrm{Cu}^{2+}$ and $\mathrm{H}_{2} \mathrm{O}_{2}$ [11], generating more species of catalyst available to react with the analyte, and promoting higher currents due to the reduction of cupric to cuprous ions.

Finally, graphs were constructed in order to confirm that the sensor presented a hyperbolic profile, as expected for a biomimetic sensor (inset in Fig. 8), and to obtain an apparent Michaelis-Menten constant ( $\mathrm{K}_{\mathrm{MM}}^{\mathrm{app}}$ ) for the NF sensor. The Lineweaver-Burk graph (Fig. 8) enabled calculation of a value of $2.8 \times 10^{-3} \mathrm{~mol} \mathrm{~L}^{-1}$, which is in line with values expected for enzymatic and biomimetic catalysts [10], and also indicative of a high affinity between the catalyst (copper complex) and the analyte.

Consideration of all of the experimental evidence, provided above, suggested that the sensor constructed using the poly-CuPc complex in Nafion ${ }^{\circledR}$ doped film on a GCE was biomimetic.

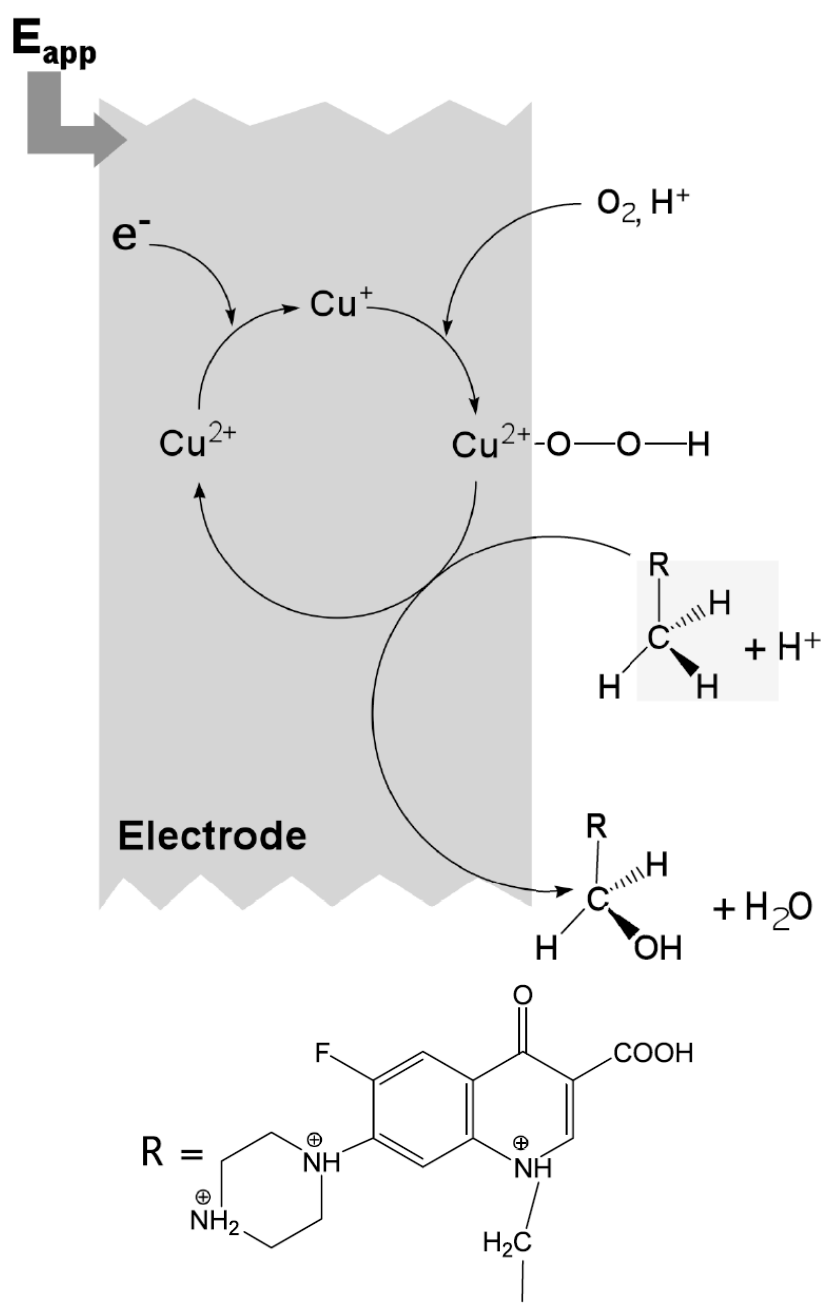

Fig. (7). Proposed mechanism for the sensor response, based on the experimental evidence, with copper-hydroperoxy formation followed by hydrocarbon hydroxylation of NF.

\subsection{Optimization and Analytical Characteristics of the Sensor}

The amperometric technique was used for optimization of sensor performance. The parameters evaluated included the nature and concentration of the electrolyte solution, the applied potential and the amount of copper complex in the sensor film. The sensor prepared with a Nafion ${ }^{\circledR}$ film obtained from a $5 \mathrm{mg} \mathrm{mL}^{-1}$ solution of poly-CuPc in DMF showed the best performance in $0.1 \mathrm{~mol} \mathrm{~L}^{-1}$ acetic acid containing $1.5 \mathrm{mmol} \mathrm{L}^{-1} \mathrm{H}_{2} \mathrm{O}_{2}$, with an applied potential of $0.05 \mathrm{~V} v s \mathrm{Ag} \mid \mathrm{AgCl}$.

The amperometric profile of the biomimetic sensor under optimized conditions is shown in the inset of Fig. (9). The linear response for norfloxacin detection was from 0.2 to 1.2 mmol L-1 (Fig. 9), with a sensitivity of $2272 \pm 84 \mu \mathrm{A} \mathrm{L} \mathrm{mol}^{-}$ ${ }^{1}$, and limits of detection and quantification of $4.0 \mu \mathrm{mol} \mathrm{L}^{-1}$ and $1.3 \times 10^{-5} \mathrm{~mol} \mathrm{~L}^{-1}$, respectively [42]. A linear correlation coefficient of 0.995 was obtained, and the data in Fig. (9) could be described by:

$\Delta \mathrm{i} / \mu \mathrm{A}=0.3( \pm 0.1)+2272( \pm 84)[\mathrm{NF}] / \mathrm{mol} \mathrm{L}^{-1}$ 


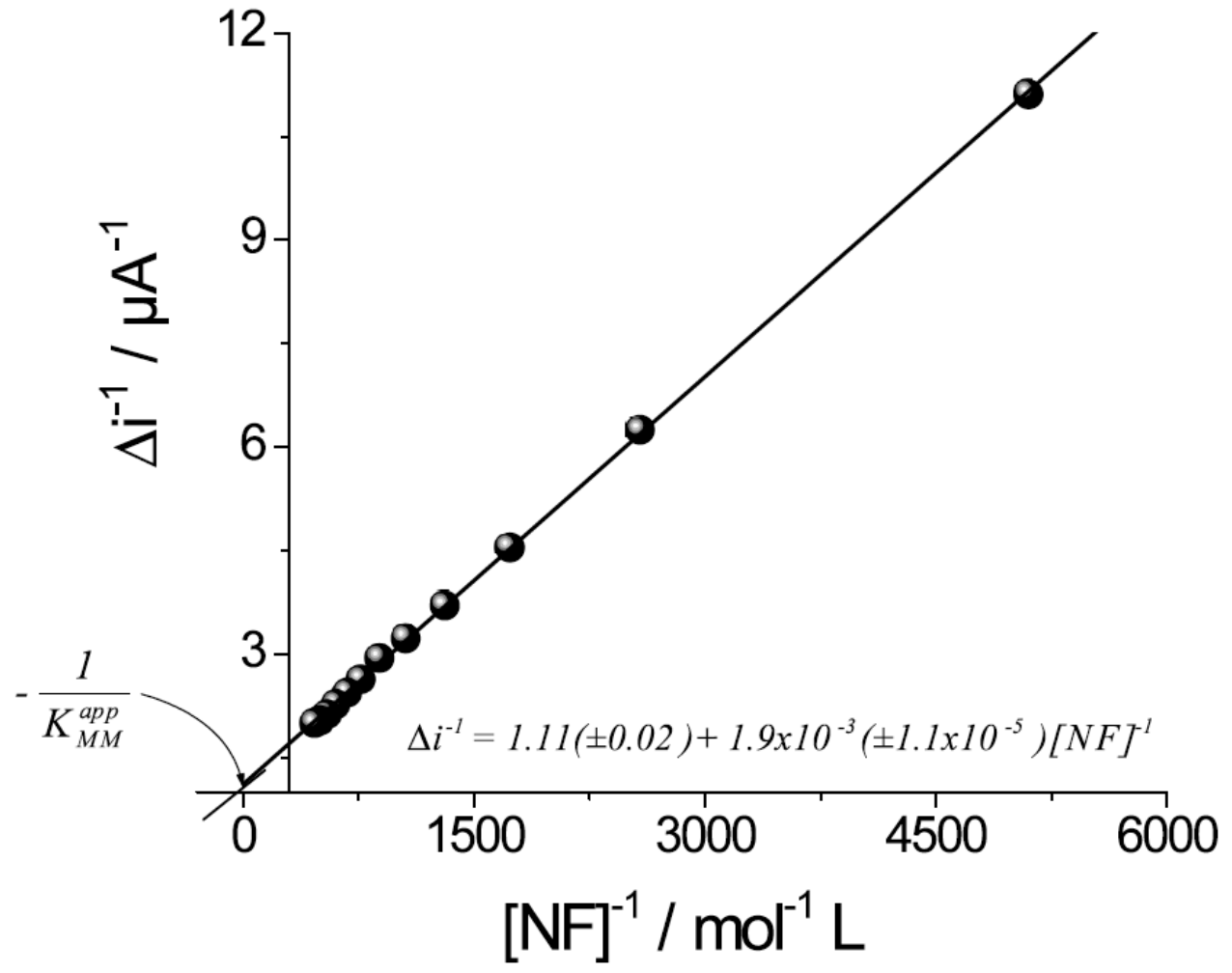

Fig. (8). Lineweaver-Burk plot for the catalyzed oxidation of $\mathrm{NF}$ on the poly(CuPc)-based sensor. Inset: the hyperbolic response presented by the biomimetic sensor.

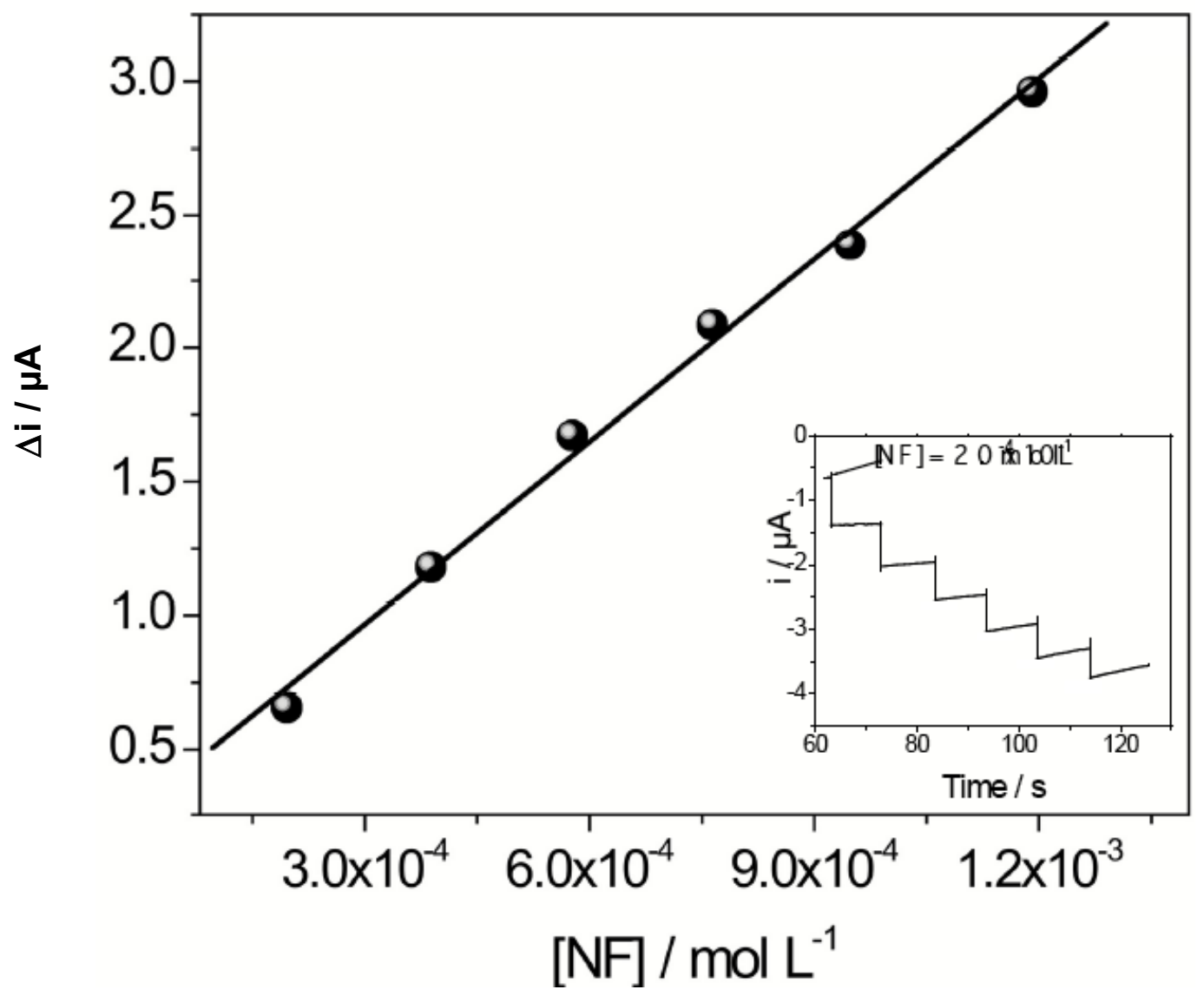

Fig. (9). Typical analytical curve profile of the proposed sensor for determination of NF under optimized conditions. Inset: chronoamperometric measurement for successive additions of analyte. 
The repeatability of the measurements was evaluated using five analytical curves constructed on the same day, and resulted in a relative standard deviation (R.S.D.) value of $2.5 \%$. The sensor could be kept at room temperature and used for several months (more than 100 days), with a sensitivity value retention of $56 \%$.

\subsection{Sensor Selectivity}

Selectivity was investigated in detail for the poly $(\mathrm{CuPc})$ based sensor. In addition to NF (Chart 1a), the response of the sensor was tested for nine other solutions containing the following pharmaceuticals (Chart 1): nalidixic acid (b) and ciprofloxacin (c), which possess structures analogous to that of NF; acetaminophen (d), a phenolic compound; acetylsalicylic acid (e); amoxicillin (f); captopril (g); chloramphenicol (h); diclofenac (i); and dipyrone (j). The amperometric experiments showed that the biomimetic sensor did not present a signal for compounds $\mathbf{c}$ and $\mathbf{e}-\mathbf{j}$. For compounds $\mathrm{b}$ and $\mathrm{d}$, for which the sensor presented a response, the sensitivities obtained were $86 \%$ and $23 \%$, respectively, of the sensitivity obtained for NF.

It important to note that the sensor showed a response for nalidixic acid, but not for ciprofloxacin. This result suggests that the moiety on the NF molecule involved in the sensor mechanism is one containing the alkyl group, which is also present in the nalidixic acid molecule (Chart 1b), justifying the high sensitivity value shown by the proposed sensor for nalidixic acid, as well as the proposed mechanism shown in Fig. (8). However, since the solubility of nalidixic acid is lower than that of NF, no problem was found in the analytical sensor application.

The sensor response for paracetamol (Chart 1d) can be justified by consideration of the phenolic structure of the molecule, with the behavior as expected since it is known that the $\mathrm{Cu}^{2+}-\mathrm{O}-\mathrm{O}-\mathrm{H}$ species can also catalyze the oxidation of phenolic compounds, as suggested in the proposed mechanism.

\subsection{Sensor Application}

Application of the proposed sensor was tested in analysis of the five commercial pharmaceutical formulations and the five river water samples. For the latter, the samples were enriched with NF in order to demonstrate the applicability of the proposed sensor to environmental media.

A detailed study was carried out to evaluate interferences, before demonstrating the sensor application in commercial formulations, in order to examine the effects of the excipients on the sensor response. Different mass ratios between the interfering compounds and NF were tested. The tabulated values (Table 1) correspond to currents obtained by the sensor in the presence of a mixture of NF and the interfering species, divided by the signal obtained for $\mathrm{NF}$

Table 1. Recovery Values (\%) for $8.0 \mathrm{mg} \mathrm{mL}^{-1} \mathrm{NF}$ in the Presence of Interfering Compounds with Different Mass/Mass Ratios. Measurements were Carried out in $0.1 \mathrm{~mol} \mathrm{~L}^{-1}$ Acetic Acid Containing $1.5 \times 10^{-3} \mathrm{~mol} \mathrm{~L}^{-1} \mathrm{H}_{2} \mathrm{O}_{2}$. The Applied Potential was $50 \mathrm{mV}$ vs Ag|AgCl

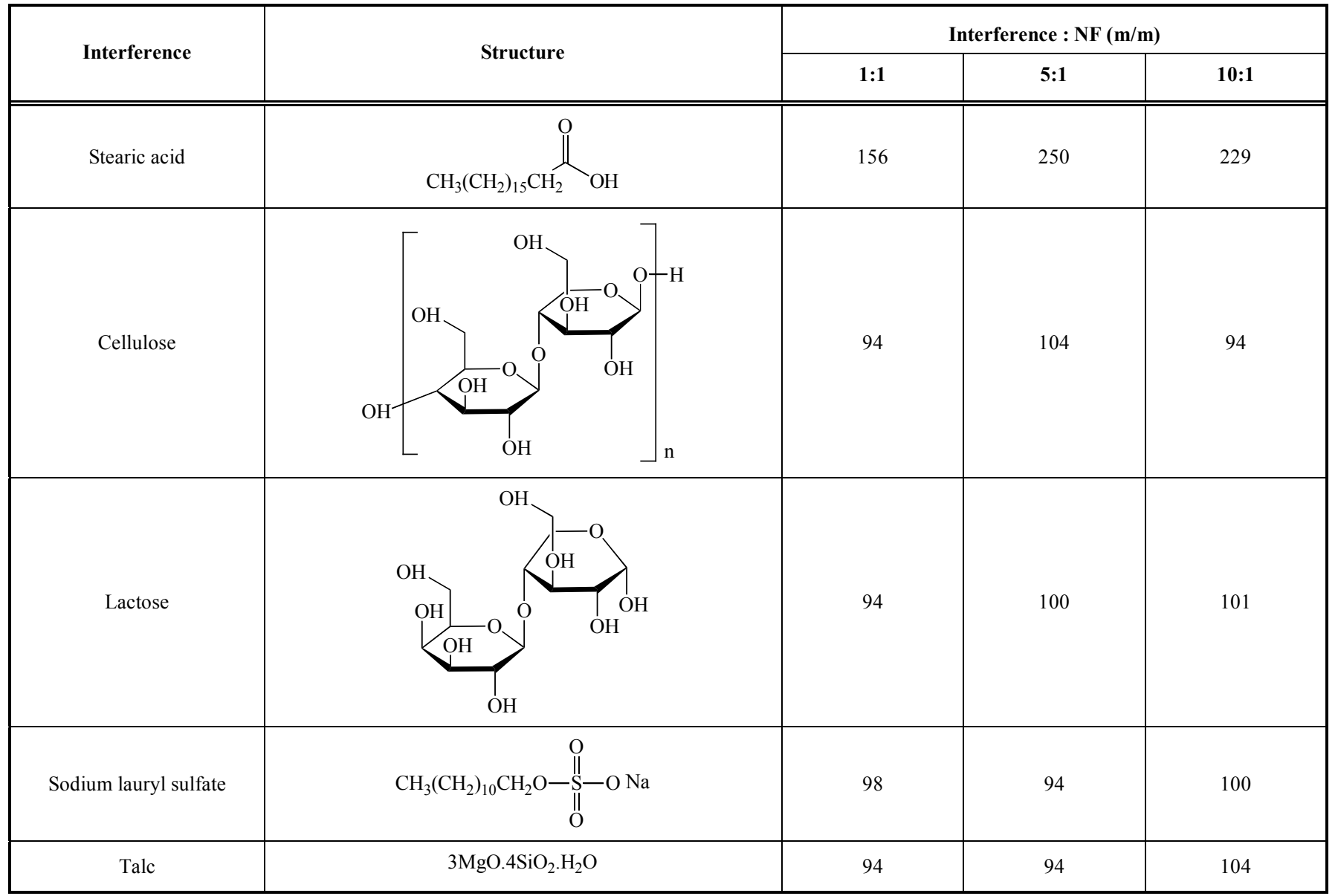


Table 2. Determination of Norfloxacin in Pharmaceutical Formulations Using the Proposed Sensor and the Chromatographic Method as Reference

\begin{tabular}{|c|c|c|c|c|}
\hline \multirow{2}{*}{ Sample } & \multirow{2}{*}{ Label Value/mg Tablet ${ }^{-1}$} & \multicolumn{2}{|c|}{ Experimental Value } & \multirow{2}{*}{ Error (\%) } \\
\hline & & Comparative Method (HPLC) & Proposed Sensor & \\
\hline Flox $^{\text {TM }}($ LAH1782, 01/11) & 400 & 495 & 477 & 3.8 \\
\hline Floxacin $^{\circledR}($ LKE007, 11/11) & 650 & 670 & 659 & 1.7 \\
\hline $\operatorname{Norf}^{\circledR}(L 231758,06 / 11)$ & 400 & 428 & 409 & 4.6 \\
\hline Norfloxmed (L2321, 07/11) & 400 & 388.5 & 405 & 4.1 \\
\hline Uritrat (L09F0109, 05/11) & 400 & 383.6 & 383.2 & 0.1 \\
\hline
\end{tabular}

Table 3. Recovery Values Obtained with the Proposed Sensor for River Water Samples Fortified with Norfloxacin

\begin{tabular}{|c|c|c|}
\hline \multirow{2}{*}{ River } & \multicolumn{2}{|c|}{ NF $\left(\mathbf{m o l} \mathbf{L}^{-1}\right)$} \\
\cline { 2 - 3 } & Recovery $\%$ \\
\hline \hline Jacaré Guaçú & $1.25 \times 10^{-2}$ & $1.17 \times 10^{-2}$ \\
\hline Jacaré Pepira & $1.25 \times 10^{-2}$ & $1.16 \times 10^{-2}$ \\
\hline Jaú & $1.25 \times 10^{-2}$ & $1.17 \times 10^{-2}$ \\
\hline Tietê river on the outskirts of Igaraçu city & $1.25 \times 10^{-2}$ & $1.24 \times 10^{-2}$ \\
\hline Tietê river under the bridge in Barra Bonita city & $1.25 \times 10^{-2}$ & 93.6 \\
\hline
\end{tabular}

alone, and then multiplied by 100 . It can be observed that stearic acid, a long chain hydrocarbon, interfered with NF quantification, probably due to hydrocarbon hydroxylation. This result provides further evidence of the plausibility of the proposed mechanism.

On the other hand, this result suggested the existence of a matrix effect in the analysis of the commercial NF tablets containing this excipient. In order to overcome this problem, analysis of the commercial NF tablets should therefore be carried out using the standard additions quantification method. The results obtained were compared with those obtained using the HPLC reference method [34] (Table 2). The results obtained by the proposed sensor and by the HPLC method were not statistically different (at the $95 \%$ confidence level).

For application in aquatic environments, Table $\mathbf{3}$ shows that acceptable NF recovery values were achieved for the river water samples, demonstrating that the sensor can be successfully used for the direct analysis of surface waters.

\section{CONCLUSIONS}

This work describes an alternative methodology for the determination of NF, using a sensitive amperometric sensor based on poly-CuPc, immobilized on a GCE surface using a very robust Nafion ${ }^{\circledR}$ membrane. The results obtained suggested that this copper complex could be considered a biomimetic catalyst, and a plausible mechanism for the sensor response was proposed, based on the experimental evidence. The sensor was satisfactorily applied in analyses of drug tablets, and its successful application in river water samples was demonstrated through recovery experiments.

\section{ACKNOWLEDGEMENTS}

The authors gratefully acknowledge financial support from FAPESP (Proc. 2008/00303-5). DFG is indebted to FAPESP (Proc. 2009/01078-8) for a fellowship.

\section{REFERENCES}

[1] Skoog, D.A.; Holler, F.J.; Nieman, T.A. Principles of Instrumental Analysis. th $^{\text {th }}$ ed.; Saunders College: NewYork, 1997.

[2] Wang, Z.; Zhang, H.; Zhou, S. Determination of trace amounts of dipyridamole by stripping voltammetry using a Nafion modified electrode. Talanta, 1997, 44, 621.

[3] Wang, J.; Bonakdar, M.; Morgan, C. Voltammetric measurement of tricyclic antidepressants following interfacial accumulation at carbon electrodes. Anal. Chem., 1986, 58, 1024.

[4] Richter, P.; Toral, M.I.; Vargas, F.M. Polarographic behaviour and determination of ranitidine in pharmaceutical formulations and urine. Analyst, 1994, 119, 371.

[5] Tunçel, M.; Yazan, Y.; Dogrukol, D.; Atkosar, Z.A. A polarographic study on dipyridamole and its determination in comercial tablets. Anal. Lett., 1991, 24, 10.

[6] Lin, N.S.; Jan, B.I. A sensitive measurement of maleic hydrazide by a differential pulse voltammetry followed by a cleansing pulse train. J. Chin. Chem. Soc., 1999, 46, 879.

[7] Wang, E.; Hou, W. Determination of water-soluble vitamins using high-performance liquid chromatography and electrochemical or absorbance detection. J. Chromatogr. A, 1988, 447, 256.

[8] Carvalhal, R.F. Thesis. Desenvolvimento de sensor biomimético empregando monocamadas auto-organizadas de tióis sobre eletrodos de ouro. Universidade Estadual de Campinas, 2005; p. 15.

[9] Sotomayor, M.D.P.T. ; Kubota, L.T. Enzymeless biosensors: uma nova área para o desenvolvimento de sensores amperométricos. Quim. Nova, 2002, 25, 123.

[10] Sotomayor, M.D.P.T.; Tanaka, A.A.; Freire, R.S.; Kubota, L.T. Amperometric sensors based on biomimetic catalysts. In Encyclopedia of Sensors; American Scientific Publishers, Ed.; ASC: California, 2006, vol. 1, p. 195. 
[11] Sotomayor, M.D.P.T.; Tanaka, A.A.; Kubota, L.T. Development of an enzymeless biosensor for the determination of phenolic compounds. Anal. Chim. Acta, 2002, 455, 215.

[12] Batista, I.V.; Lanza, M.R.V.; Dias, I.L.T.; Tanaka, S.M.C.N.; Tanaka, A.A.; Sotomayor, M.D.P.T. Electrochemical sensor highly selective for estradiol valerate determination based on a modified carbon paste with iron tetrapyridinoporphyrazine. Analyst, 2008, $133,1692$.

[13] Oliveira, M.C.Q.; Lanza, M. R.V.; Tanaka, A.A.; Sotomayor, M.D.P.T. Flow injection analysis of paracetamol using a biomimetic sensor as a sensitive and selective amperometric detector. Anal. Methods, 2010, 2, 507.

[14] Santos, W.J.R.; Sousa, A.L.; Sotomayor, M.D.P.T. Damos, F.S.; Tanaka, S.M.C.N.; Kubota, L.T.; Tanaka, A.A. Manganese phthalocyanine as a biomimetic electrocatalyst for phenols in the development of an amperometric sensor. J. Braz. Chem. Soc., 2009, 20, 1180 .

[15] Souza, M. V. N.; Almeida, M. V.; Silva, A. D.; Couri, M. R. C. Ciprofloxacina, uma importante fluorquinolona no combate ao antraz. Rev. Bras. Farm., 2004, 85, 13.

[16] Wankhede, S.D.; Prakash, A.; Kumari, B.; Chitlange, S.S. Simultaneous spectrophotometric estimation of norfloxacin and ornidazole in tablet dosage form. Indian J. Pharm. Sci., 2009, 71, 325.

[17] Yu, X.; Bao, J. Determination of norfloxacin using gold nanoparticles catalyzed cerium(IV)-sodium sulfite chemilumine-scence. Luminescence, 2009, 129, 973.

[18] Pérez-Ruiz, T.; Martínez-Lozano, C.; Tomás, V.; Carpena, J. Determination of norfloxacin in real samples by different spectrofluorimetric techniques. Analyst, 1997, 122, 705.

[19] Polishchuk, A.V.; Karaseva, E. T.; Medkov, M. A.; Karasev, V. E. europium(III) compounds with cyprofloxacine and norfloxacine: spectral and luminescent properties and antibacterial activity. Russ. J. Coord. Chem., 2004, 30, 828 .

[20] Conkle, J.L; Lattao, C.V.; White, J.R.; Cook, R.L. Pharmaceutical analysis for environmental samples: individual and simultaneous determination of ciprofloxacin, ofloxacin and norfloxacin using an HPLC with fluorescence and UV detection with a wetland soil matrix. Anal. Lett., 2009, 42, 2937.

[21] Esponda, S.M.E.; Padrón, M.E.T.; Ferrera, Z.S.F.; Rodríguez, J.J.S. Solid-phase microextraction with micellar desorption and HPLCfluorescence detection for the analysis of fluoroquinolones residues in water samples. Anal. Bioanal. Chem., 2009, 394, 927.

[22] Li, B.; Zhang, T.; Xu, Z.; Fang, H.H.P. Rapid analysis of 21 antibiotics of multiple classes in municipal wastewater using ultra performance liquid chromatography-tandem mass spectrometry. Anal. Chim. Acta, 2009, 645, 64.

[23] Tang, Q.; Yang, T.; Tan, X.; Luo, J. Simultaneous determination of fluoroquinolone antibiotic residues in milk sample by solid-phase extraction-liquid chromatography-tandem mass spectrometry. Agric. Food Chem., 2009, 57, 4535.

[24] Shao, B.; Chen, D.; Zhang, J.; Wu, Y.; Sun, C. Determination of 76 pharmaceutical drugs by liquid chromatography-tandem mass spectrometry in slaughterhouse wastewater. J. Chromatogr. A, 2009, 1216, 8312 .

[25] Ballesteros, O.; Toro, I.; Sanz-Nebot, V.; Nabalón, A.; Vilchez, J.L.; Barbosa, J. Determination of fluoroquinolones in human urine by liquid chromatography coupled to pneumatically assisted electrospray ionization mass spectrometry. J. Chromatogr. B: Anal. Technol. Biomed. Life Sci., 2003, 798, 137.
[26] Collado-Sanchez, M.A.; Rambla-Alegre, M.; Carda-Broch, S.; Esteve-Romero, J. Simultaneous separation and determination of quinolones in pharmaceuticals by micellar liquid chromatography. J. Liq. Chromatogr. Relat. Technol., 2010, 33, 513.

[27] Lombardo-Agui, M.; Gámiz-Gracia, L.; García-Campaña, A.M.; Cruces-Blanco, C. Sensitive determination of fluoroquinolone residues in waters by capillary electrophoresis with laser-induced fluorescence detection. Anal. Bioanal. Chem., 2010, 396, 1551.

[28] Jaber, A.M.Y.; Lounicia, A. Polarographic behaviour and determination of norfloxacin in tablets. Anal. Chim. Acta, 1994, 291,53 .

[29] Zhao, L.; Dong, Y.H.; Wang, H. Residues of veterinary antibiotics in manures from feedlot livestock in eight provinces of China. Sci. Total Environ., 2010, 408, 1069.

[30] Hamscher, G.; Sczesny, S.; Höper, H.; Nau, H. Determination of persistent tetracycline residues in soil fertilized with liquid manure by high-performance liquid chromatography with electrospray ionization tandem mass spectrometry. Anal. Chem., 2002, 74, 1509.

[31] Campagnolo, E.R.; Johnson, K.R.; Karpati, A.; Rubin, C.S.; Kolpin, D.W.; Meyer, M.T. Antimicrobial residues in animal waste and water resources proximal to large-scale swine and poultry feeding operations. Sci. Total Environ., 2002, 299, 89.

[32] Yang, W.; Carlson, K. Evolution of antibiotic occurrence in a river through pristine, urban, and agricultural landscapes. Water Res., 2003, 37, 4645.

[33] Sigoli, A.; Lanza, M.R.V.; Tanaka, A.A.; Kubota, L.T.; Sotomayor, M.D.P.T. Construction and application of an electrochemical sensor for paracetamol determination based on iron tetrapyridinoporphyrazine as a biomimetic catalyst of $\mathrm{P} 450$ enzyme. J. Braz. Chem. Soc., 2008, 19, 734.

[34] Borrego, M.C.; Díaz, M.C.; Díaz, D.C. Validation of a highperformance liquid chromatographic method for the determination of norfloxacin and its application to stability studies (photostability study of norfloxacin). J. Pharm. Biom. Anal. 1999, 18, 919.

[35] Damos, F.S.; Sotomayor, M.D.P.T.; Kubota, L.T.; Tanaka, S.M.C.N.; Tanaka, A.A. Iron(III) tetra-( $N$-methyl-4-pyridyl)porphyrin as a biomimetic catalyst of horseradish peroxidase on the electrode surface: An amperometric sensor for phenolic compound determinations. Analyst, 2003, 128, 255.

[36] Klinman, J.P. Mechanisms whereby mononuclear copper proteins functionalize organic substrates. Chem. Rev., 1996, 96, 2541.

[37] Stewart, L.C.; Klinman, J.P. Characterization of alternate reductant binding and electron transfer in the dopamine beta.monooxygenase reaction. Biochemistry, 1987, 26, 5302.

[38] Fontecave, M.; Pierre, J.-L. Oxidations by copper metalloenzymes and some biomimetic approaches. Coord. Chem. Rev., 1998, 170, 125.

[39] Williams, N.K.; Klinman, J.P. Whence topa? Models for the biogenesis of topa quinone in copper amine oxidases. J. Mol. Catal. B Enzym., 2000, 8, 95.

[40] Andrieux, C.P.; Savéant, J.M.J. Heterogeneous (chemically modified electrodes, polymer electrodes) $v s$ homogeneous catalysis of electrochemical reactions. Electroanal. Chem., 1978, 93, 163.

[41] Bard, A.J.; Faulkner, L.R. Electrochemical Methods: Fundamentals and Applications; $2^{\text {nd }}$ ed., John Wiley \& Sons, Inc.: New York, 2001.

[42] Currie, L.A. Nomenclature in evaluation of analytical methods including detection and quantification capabilities: (IUPAC Recommendations 1995). Anal. Chim. Acta, 1999, 391, 105. 